\title{
Relationship Trading, Internal Control and Corporate Cash Holding
}

\author{
Zhonggao Lin ${ }^{1, a}$, Ruilan Cao ${ }^{2, b,{ }^{*}}$, Pei Tang ${ }^{3, c}$ \\ ${ }^{1}$ School of Business, Anhui University of Technology, Ma'anshan, P. R. China \\ ${ }^{2}$ School of Foreign Languages, Anhui University of Technology, Ma'anshan, P. R. China \\ ${ }^{3}$ School of Business, Anhui University of Technology, Ma'anshan, P. R. China \\ alinzhg@163.com, b630080335@qq.com, c447900389@qq.com
}

Keywords: Customer Relationship Trading, Supplier Relationship Trading, Internal Control, Cash Holding.

\begin{abstract}
Being different from the previous research, this paper studies the influence of relationship trading on cash holding and the adjustment function of internal control based on the principal status of relationship trading in market. Results show that customer relationship trading leads to the decrease of corporate cash holding while supplier relationship trading the increase, and that this kind of relationship will change according to different market positions of all parties in trades. Further research demonstrates that internal control has significant but opposite effect on this influence. It has been found that relationship trading is an important measure taken by cooperation in reaction to the instability of external environment and the realization of reinforcing the corporation for a win-win, but the double-edged sword has different economic effects on cash holding. Therefore, establishing a comprehensive and effective internal control system is the requirement of ensuring the scientific management. It could be an essential mechanism to protect the profits of all parties in trading, which displays the important value of internal control of allocating interests.
\end{abstract}

\section{Introduction}

As a very efficient tool of trade, relationship is widely used in business activities, especially in the enterprise transactional model in countries of economic transition, but it is also a double-edge sword as a business model that has both opportunism and efficiency. From the perspective of efficiency, by forming the integrated relationship of suppliers and customers of upstream and downstream firms, trade cost can be reduced, value can be created, competitive edge can be gained and thus it becomes a crucial source for dealing with market climate change with core abilities [1][2][3]. From the perspective of opportunism, relationship trading is characterized by its narrow private trade, so non-relationship trade companies can hardly observe the private information of core suppliers or customers and it is difficult for them to predict the probable financial damage induced by the ending of this relationship so that the imbalance of the whole market's information system will be exacerbated [4]. Also, once either party withdraws from the transaction, the manufacturing or marketing will be influenced, which may also be taken as a threat [5] and then leads to moral risk or the scheme of transferring capital within relevant insiders [6][7][8], which will be bad for the management, the quality of accountants information, etc. [9][10][11]. Given the negative effects of relationship trading, the two parties may keep this trading pattern for establishing loner-term mutual relation [12] or they need to disseminate positive messages about 
their own financial status to the other party in order to encourage the other party's investment of specific assets. Besides, for making the other party believe that they can keep the performance capacity of implementing the recessive relationship trading contract, the enterprises will be inclined to keep the relatively good asset liquidity of cash [13]. Despite that several scholars have studied the relativity between relationship trading and cash holding, their research findings vary greatly and they mostly have ignored the effects of the power (position) of both markets since in both cases, customers and suppliers exert different influences on the level of cash holding, which gives important opportunities for the article to delve deeper.

In addition, investigating from the motivation of cash holding in companies, internal control has significant influence over the level of cash holding [14][15], and thus alter the influential efficacy and direction of relationship trading to cash holding level. In emerging marketing countries, most are faced with typical financing control problems as companies have to face many uncertainties of the market and in view of preventative motivation, enterprises will usually hold more cash. However, when the enterprises lack efficient control and management cash, the motivation deviates from the original purpose due to the agency of management. To put it simply, because of preventative motivation, companies intend to keep more cash, and in return, agency problem will make them not willing to do so. From the aspect of preventative motivation, cash holding is a precaution for future uncertainties, so when the degree of relationship trading is high, this kind of motivation will render excess cash to the corporation; and in view of commitment motivation, the supplier can hold extra cash as a commitment for not getting stuck in financial dilemma in order to ensure the buyer's partial optimal investment. The change in relationship trading will lead to the change in cash holding motivation and quantity while both of them affect the degree of relationship trading. Therefore, in such complex relations, how does the internal control system work as a key component of internal management to play its adjustment role or whether it actually does? This is another issue inspiring this research.

Based on the above, this article takes Shanghai-Shenzhen A-share listed companies in 2009-2015 as an example to study the influence of relationship trading on corporate cash holding level in different market environments as well as the adjustment function of internal control. The major contributions of this research are found in: (1) Expanding the scope of literature review. Previous researches mainly focused on customer relationship trading and results vary greatly of the few researches on supplier relationship trading and its cash holding. Therefore, this article, based on existing research, further differentiates supplier relationship trading and customer relationship trading in buyer's and seller's markets so as to reveal the elements of relationship trading that influence the position (power) of cash holding, helping deepen the content in this regard and widen the scope of the literature. (2) Providing new path to the establishment and perfection of internal control for enterprises. Under the occasion where market and legal climates in our country are still not complete, relationship trading becomes a vital mode for enterprises, but due to its dual character, the internal control plays a great part in restraining the negative effects of relationship trading. Therefore, how to make the best use of the advantages and bypass the disadvantages of relationship trading shall be seriously considered in the construction of internal control by enterprises.

\section{Theoretical Analysis and Research Hypothesis}

\subsection{Relationship Trading and Cash Holding}

During the initial stage of relationship trading, corporations are inclined to disseminate positive information about its own financial status in order to establish and maintain good and stable 
relationships with the upstream and downstream firms in the supply chain. Tang (2009) found that the ability of negotiating of a corporation's suppliers and customers can significantly influence corporation management [16]. Furthermore, Kai Wai Hui et al. (2012) revealed that when the ability of negotiating of a corporation's main suppliers and customers is high, the management usually adopts stable policy to maintain the cooperative relationship [17]. Afterwards, with the increasing intimacy, both trading partners will invest more specific investment to make the other feel good about their financial conditions and are willing to keep a long-term cooperation [13] so that the base of cooperation will last long [12]. Then what kind of influence do the varied directions of relationship trading have on cash holding?

From the supplier's perspective, Wang \& Liu (2016) found in their research that with the increasing relativity of suppliers, corporations will have lots of cash and it is mainly based on commitment motivation instead of preventative motivation [18]. Zhao \& Bao (2015) found that the number of cash they hold increases with the level of relationship trading, which will be more obvious in non-SOEs of low market position [19]. Building steady and long-term relationship with major clients brings steady and long-lasting profits and helps keep a steady market share and shares intrinsic values with intimate companies so as to further obtain relationship special investment through good relations with major clients. Nevertheless, when the market is in an excessively fierce environment, it would be very risky to overly rely on relationship trading. For instance, depending too much on major clients will weaken the negotiating ability of a corporation in face of other clients of the market while the major clients cannot fully ensure continuing purchasing in the future. Once the close relationship is broken, the corporation will lose a great many of accesses for sales and even fail to recollect the prior payment for goods which leads to lots of bad debts and thus, the cash flow disorder happens. Besides, from the view of banks, losing major clients is a sign of bad performance, which will trigger the turning-down of corporate credit line by banks, which puts a corporation into a more serious financial predicament. Based on the consideration of both opportunities and risks, companies with high level of relationship trading usually choose a relatively stable financial policy so as to make a commitment for its own stable financial status to remove the concerns of its customers over cooperation risks. At the same time, it can effectively prevent the fluctuation of cash flow induced by the loss of major clients or that of power. As a result, corporations with high level of relationship trading can avoid the financial predicament induced by the capital chain rupture.

From the customer's perspective, Jennifer Itzkowitz (2013) found that when the customer relationship trading level is high, the company may have to seek for new clients if the major clients breach the contract, which will probably render products unsalable and payment return stunted, leading the risk to be very high. In order to prevent it, a corporation intends to hold more cash, which means the suppliers' cash holding level is in a significantly positive correlation with the customer relationship treading [20]. In the seller's market, the goods of suppliers are not easy to be replaced by products offered by others, so the suppliers will require clients to pay before delivering goods, and the corporation will have more incentive to enhance the relationship with its suppliers to stabilize the relationship trade. In the process of making upstream and downstream trade, the supplier, as a seller, gain the profits from selling products while the corporation, as the buyer, obtain the subject matter through paying cash and satisfy the supplier with their affordability. Cash, as the most acceptable capital with the most typical flow property, is the most direct display of the buyers' performances. Therefore, it is a more effective way to hold cash through which the supplier can sense the corporation's commitment for payment in time. In addition, the supplier, as the seller, is 
more sensitive about the relationship value with the cash holding in the corporation which is more effective. The termination of a close relationship has more direct and severe impact on the suppliers' cash flow. Given the above reasons, companies may hold more cash out of commitment drive with the increasingly intimate relationship between the enterprise and the supplier. However, studying from the view of macro-economy, our country has gradually entered the buyer's market since 1996, and the supplier offered various preferential measures to occupy the market and attract customers, such as delivering goods before payment so that the clients will not have to hold a large number of cash to keep the stability of upstream trade. There has even been the phenomenon: the higher the ratio of supplier relationship trading, the more trust the supplier and the customer have toward each other. Thus, the client can use the stocked cash for the daily management and investment of the corporation. In the buyer's market, the corporation has plenty choices of suppliers, and then it will not spend much on negotiation for seeking a new supplier if the relationship trading with the supplier is broken. In sum, in the buyer's market, the supplier is in a passive position as they seek for a more stable and higher marketing channel as well as stable clients. Clients who have stable suppliers can use cash for other business activities, which means the rising relationship trading needs no increase but decrease of cash holding in the perspective of the clients. By all accounts, the followings contribute to Hypothesis 1.

H1(a): Other things being equal, corporate cash holding level increases with the increase of customer relationship trading.

H1(b): Other things being equal, corporate cash holding level decreases with the increase of supplier relationship trading.

\subsection{Regulating Effects of Internal Control on the Influence of Relationship Trading upon Corporate Cash Holding}

Internal control comes along with organization, and it is for ensuring the release credibility of financial report, the effect and efficiency of corporate management and the adherence to the existing laws and regulations (COSO 2013). All the elements coordinate and connect with each other, giving feedback in responding to the change of situation as a whole. Therefore, a good internal control environment could low down the negative effect caused by information asymmetry, and play the regulating role in various cash holding levels. Excessive cash holding would lead to excessive investment, while insufficient one would bring about the loss of regulation in preventing operating uncertainty. Considering the Agency Cost Hypothesis and precautionary motive, both excessive and insufficient cash holdings have negative effects on corporate running. On the one hand, internal control would affect the corporate financial policies made by the management through reducing information asymmetry, agency cost and financing cost, with the corporate operation efficiency increase following, so in turn with the management credibility, which would help seize the best financing opportunity and more capital to be used in investment. Zhang \& Wu (2014) proposed that better internal control could remarkably increase the value of corporate cash holding [14]. The quality of internal control could curb excessive investment and reduce the agency cost, thus, the corporation could employ the cash in stock highly efficiently in response to future uncertainty. Wang \& Song (2014) proposed that internal control could not only improve the truth and integrity of the information, but also increase corporate operation efficiency [15]. Internal control could affect the size of cash holding and the effects would be much more obvious when the relationship trade becomes more frequent and the information gets more asymmetric. Besides, corporate information is of higher quality with better internal control, and the negative results come from 
closely related relationship trading will reduce as well. In the meantime, development of internal control and the protection for investors could reduce corporate cash holding to a certain degree. Higher internal control assures the reliability of accounting information and reduces the corporate external financing cost which could decrease corporate cash holding since it is unnecessary for corporations to accumulate internal capital [21].

Over-reliance on relationship trading results in serious information asymmetry, and more developed trade would increase the gravity of potential information asymmetry existing in the corporation. While in the meantime, corporate bargaining ability and capacity of responding to the change in the market will reduce substantially. By weighing the cash holding's liquidity returns and agency cost, the cash holding level would reach to an equilibrium state, where the quality of internal control represents one of the major factors that influence cash holding level [22]. Many scholars hold that companies would miss its beneficial investment opportunities for the cash flow shortages without adequate cash reserve, resulting in difficulties of corporate sustainable development; reversely, it will contribute to corporate improvement and development of performance if there is enough cash reserve. However, Free Cash Flow Theory believes that corporate agent tends to hold more cash so as to maximize the personal interest. They might apply the excessive cash to increase personal income or make improper decisions against the shareholder interest maximization, leading to excess investment. Harford (2004) proved that the merger and acquisition of diminishing value is much more likely to arise in the corporation with adequate cash than those without, which is mainly manifested in two aspects: a. falling stock market caused by acquisition announcement; b. decline in operating performance after acquisition [23]. Chen \& Weng (2004) found that corporations with cash more than enough would see a decline in corporate performance as the increase in cash holding [24]. Given all, both excessive and low cash holdings are unfavorable to corporate management and development. Different cash holding levels certainly lead to the difference in the regulatory role the internal control plays in the cash holdings connected to the relationship trading.

In order to further investigate how internal control affects the fluctuation of cash holding, this article takes both internal control and relationship trading into consideration. It is observed that under different levels of cash holding, how internal control influences the change of cash holding caused by relationship trading. The more advanced relationship trading and the higher degree of information asymmetry would make it much easier for internal control to improve the quality of information and low down the agent cost and finally affect the size of cash holding. From the point of commitment to motivation for cash holding in relationship trading, the trust of the relationship trading partner would increase when the quality of internal control is higher, and the agency motive of cash holding diminishes. Those indicate that internal control exerts different influence on cash holding levels from different perspectives. When cash holding is at a higher level, it is unfavorable to the corporation beyond doubt if customer relationship trading makes cash holding continue to increase. However, when cash holding is at a lower level, it is still unfavorable to corporate management due to the fact that close supplier relationship trading results in less cash in stock. Therefore, the increase in quality of internal control would ease up the change in corporate cash holding from the perspectives of customer relationship trading and supplier relationship trading. For the supplier, the increased cash holding for customer relationship trading would see a decline; for the customer, the decreased cash holding for supplier relationship trading will be relieved. By all accounts, here is Hypothesis 2.

H2(a): Other things being equal, when the cash holding level is high, the influence of customer relationship trading on cash holding decreases with the increase in quality of internal control. 
H2(b): Other things being equal, when cash holding level is low, the decrease in cash holding caused by supplier relationship trading will be mitigated.

\section{Research Design}

\subsection{Model Construction}

This article mainly studies the exact influence of relationship trading to cash holding level and explores the regulating effect of relationship trading to cash holding level when internal control is in different degrees. Hence, the research model is constructed as follows:

$$
\begin{aligned}
& \text { Cash }_{\mathrm{i}, \mathrm{t}+1}=\beta_{0}+\beta_{1} \text { Ic }_{i, t}+\beta_{2} \text { Customer }_{i, t}+\beta_{3} \text { Supply }_{i, t}+\beta_{4} \text { Customer }_{i, t} \times I c_{i, t}+\beta_{5} \text { Supply }_{i, t} \times I c_{i, t} \\
& +\beta_{6} \text { Cf }_{i, t}+\beta_{7} \text { Lev }_{i, t}+\beta_{8} \text { Size }_{i, t}+\beta_{9} \text { Beta }_{i, t}+\beta_{10} \text { Tobinq }_{i, t}+\beta_{11} \text { Cashsub }_{i, t}+\beta_{12}{\text { Cap } \exp _{i, t}} \quad \text { Accordin } \\
& +\beta_{13} \text { Listing }_{i, t}+\beta_{14} \text { Control }_{i, t}+\beta_{15} \text { tmdebt }_{i, t}+\beta_{16} \text { Dimdive }_{i, t}+\beta_{17} \text { Aud }_{i, t}+\varepsilon_{i, t}
\end{aligned}
$$

$\mathrm{g}$ to hypothesis $\mathrm{H} 1$, it is expected that the coefficient of customer is significantly positive and the supply significantly negative. According to hypothesis H2, when the cash holding level is high, the coefficient of across variable customer*ic is significantly negative and when the cash holding level is low, the coefficient of across variable supply*ic is significantly negative.

\subsubsection{Explained Variable}

The explained variable is the cash holding volume of a corporation. There are 4 measuring methods for the variable: (1) cash and cash equivalent/(total assets-cash and cash equivalent); (2) cash and cash equivalent/total assets; (3) ln [cash and cash equivalent/(total assets-cash and cash equivalent)]; (4) Cash/sales revenue. This article mainly adopts the first method for major inspection and the second one aiding for stability inspection. For avoiding endogeneity, it is decided to value the explained variable with data released a year after, and make industrial adjustments for them.

\subsubsection{Explanatory Variable}

Relationship trading explanatory variable is represented by Costomeri and Supplyi. Referring to relevant literature [16][25][26], the adopted are the ratio of the first 5 suppliers' purchase and that of the first 5 clients' sales to measure the concentration of the clients and the suppliers. The bigger the index is, the higher the level of relationship trading will be.

\subsubsection{Control Variable}

This article drew on some research findings and controlled some variables which are concretely shown in Table 1. 
Table 1: Definitions of Variables

\begin{tabular}{|c|c|c|c|}
\hline Variable Name & Variable Property & Variable Code & Variable Definition \\
\hline $\begin{array}{l}\text { Explained } \\
\text { Variable }\end{array}$ & Cash Holding Level & cash & $\begin{array}{l}\text { cash and cash equivalent/(total assets-cash and } \\
\text { cash equivalent) }\end{array}$ \\
\hline \multirow{5}{*}{$\begin{array}{l}\text { Explanatory } \\
\text { Variable }\end{array}$} & $\begin{array}{c}\text { Customer } \\
\text { Relationship Trading }\end{array}$ & customer & $\begin{array}{l}\text { ratio of the first } 5 \text { major clients' sales volume to } \\
\text { the total sales volume }\end{array}$ \\
\hline & $\begin{array}{c}\text { Supplier Relationship } \\
\text { Trading }\end{array}$ & supply & $\begin{array}{l}\text { ratio of the first } 5 \text { major suppliers' supply to the } \\
\text { amount purchased }\end{array}$ \\
\hline & $\begin{array}{c}\text { Interactive } \\
\text { Variable }\end{array}$ & customer*ic & $\begin{array}{l}\text { the products of customer relationship trading } \\
\text { and the index of internal control }\end{array}$ \\
\hline & $\begin{array}{l}\text { Interactive } \\
\text { Variable }\end{array}$ & supply*ic & $\begin{array}{l}\text { the products of supplier relationship trading and } \\
\text { the index of internal control }\end{array}$ \\
\hline & Internal Control Level & ic & the index of internal control of Dipop data base \\
\hline \multirow{13}{*}{ Control Variable } & $\begin{array}{l}\text { Undistributed Cash } \\
\text { Flow }\end{array}$ & $\mathrm{cf}$ & $\begin{array}{l}\text { undistributed Cash Flow (CF)=(the operation } \\
\text { profits before depreciation-tax amount-total } \\
\text { interest of short-term and long-term debt } \\
\text {-dividend preference-ordinary stock } \\
\text { dividend)/total assets }\end{array}$ \\
\hline & Financial Leverage & lev & $\begin{array}{l}\text { debts/total assets, representing the level of } \\
\text { corporate indebtedness }\end{array}$ \\
\hline & Corporate Size & size & natural logarithms of total assets \\
\hline & Dividend Payout & dumdive & $\begin{array}{l}\text { Dividend payout is a dummy variable. If the } \\
\text { corporation paid cash dividend at that very year, } \\
\text { the value is } 1 \text {; otherwise, } 0 \text {. }\end{array}$ \\
\hline & Risk Index & beta & $\begin{array}{l}\text { Beta is a coefficient of regression of all trading } \\
\text { return on equity of daily stocks and markets of } \\
\text { ever corporation. }\end{array}$ \\
\hline & Growth Opportunity & tobinq & $\begin{array}{l}\text { Tobinq is for controlling the growth opportunity. } \\
\text { It equals to (marketable volumexprice per } \\
\text { share+non-tradable shares } \times \text { net assets per share }+ \\
\text { book value of very share)/total assets }\end{array}$ \\
\hline & Cash Substitute & cashsub & $\begin{array}{l}\text { measuring by working capital-currency } \\
\text { capital-short-term investments/final total assets }\end{array}$ \\
\hline & Enterprise Age & listing & $\begin{array}{l}\text { measuring by the natural logarithms listing age } \\
\text { of the company }\end{array}$ \\
\hline & $\begin{array}{l}\text { Nature of Property } \\
\text { Right }\end{array}$ & control & $\begin{array}{l}\text { dummy variable. } 0 \text { for state-owned and } 1 \text { for } \\
\text { non-state-owned }\end{array}$ \\
\hline & $\begin{array}{c}\text { Structure of Debt } \\
\text { Maturities }\end{array}$ & tmdebt & current liabilities/total liabilities \\
\hline & Auditor Selection & aud & $\begin{array}{l}\text { dummy variable. } 1 \text { for business quarters of } 4 \\
\text { international or } 10 \text { domestic ones giving audit } \\
\text { report, otherwise } 0 \text {. }\end{array}$ \\
\hline & Industry & ind & $\begin{array}{l}\text { choosing manufacturing industries and } \\
\text { investigate and then control Industry. }\end{array}$ \\
\hline & Year & year & studying data of 2006-2014 and control Year. \\
\hline
\end{tabular}




\subsection{Data Source}

This article adopts some manufacturing listing companies of Shanghai-Shenzhen A-share in 2009-2015 as research samples and remove financial data deficit, actual controller absence and other deficit data of manufacturing listing companies; and the ratio of first 5 suppliers purchase and the ratio of the first 5 clients' sales are derived from manual collection and double checking from the annual reports. Listing companies' open annual report comes from Shenzhen Stock Exchange and Shanghai Stock Exchange, with the rest from CSMAR data base. In order to remove the influence of extreme value, the samples having continuing fluctuation of $1 \%$ are conducted microfilm processing and the internal control index is standardized (adopting EXCEL in data processing for the prior stage with STATA13 as the statistical software).

\section{Empirical Analysis}

\subsection{Descriptive Statistics}

The average value of listing companies' cash holding level is 0.951 , with the maximum value being 4.655, the minimum 0.0590 and the standard deviation 0.845 , all of which imply that there are apparent differences of listing companies' cash holding level among their counterparts. The average of customer concentration is 0.282 , with the maximum value being 0.903 and the minimum 0.0431 ; the supplier concentration is 0.335 , with the maximum value being 0.883 and the minimum 0.0607, which means the ratio of the sales revenue (purse expense) toward the first 5 clients to the total income (total purchase expense) has poor alignments with huge differences. The average value of internal control is 0.0013, with the maximum value being 2.382 and the minimum -5.819 . Similarly, there are also many differences of internal control quality in listing companies. Other variables have shown the differences, which renders opportunities for the study. 
Table 2 Descriptive Statistics of Major Variables

\begin{tabular}{lccccc}
\hline Variable & $\begin{array}{c}\text { Observed } \\
\text { Value }\end{array}$ & Mean Value & $\begin{array}{c}\text { Standard } \\
\text { Deviation }\end{array}$ & $\begin{array}{c}\text { Minimum } \\
\text { Value }\end{array}$ & Maximum Value \\
\hline cash & 6400 & 0.951 & 0.845 & 0.0590 & 4.655 \\
customer & 6383 & 0.282 & 0.189 & 0.0341 & 0.903 \\
supply & 5203 & 0.335 & 0.190 & 0.0607 & 0.883 \\
ic & 6400 & 0.0013 & 0.975 & -5.819 & 2.382 \\
size & 6400 & 21.86 & 1.125 & 19.72 & 25.26 \\
lev & 6400 & 0.446 & 0.195 & 0.0530 & 0.864 \\
beta & 6400 & 1.066 & 0.226 & 0.466 & 1.643 \\
cf & 6400 & 0.0469 & 0.0696 & -0.144 & 0.246 \\
tobinq & 6400 & 1.953 & 1.563 & 0.240 & 8.979 \\
cashsub & 6400 & -0.0062 & 0.189 & -0.482 & 0.436 \\
dumdivi & 6400 & 0.544 & 0.498 & 0 & 1 \\
listing & 6400 & 8.959 & 5.572 & 1 & 21 \\
capexp & 6400 & 0.0816 & 0.0961 & -0.0783 & 0.437 \\
control & 6400 & 0.534 & 0.499 & 0 & 1 \\
tmdebt & 6400 & 0.853 & 0.153 & 0.362 & 1 \\
aud & 6396 & 0.407 & 0.491 & 0 & 1 \\
\hline
\end{tabular}

\subsection{Relativity Analysis}

Table 3 listed the Pearson correlation coefficient and its significance level of variables studied. It can be seen that the coefficient of all variables are less than 0.5, which is acceptable and those of cash holding are all significant at the significance level of $10 \%$. Besides, cash holding level is in a significantly negative correlation with supplier concentration, meaning that the more a corporation depends on major suppliers, the less cash it holds; cash holding, however, is in positive correlation with client concentration, meaning that the more a corporation depends on major clients, the more cash it holds. 
Table 3 Pearson Correlation Coefficient of Major Variables

\begin{tabular}{|c|c|c|c|c|c|c|c|c|c|c|c|c|c|c|c|}
\hline & cash & $\begin{array}{l}\text { custo } \\
\text { mer }\end{array}$ & $\begin{array}{c}\text { suppl } \\
\text { y }\end{array}$ & ic & $\begin{array}{c}\text { contr } \\
\text { ol }\end{array}$ & aud & size & lev & beta & CF & $\begin{array}{c}\text { Tobi } \\
\text { nQ }\end{array}$ & $\begin{array}{l}\text { dum } \\
\text { divi }\end{array}$ & $\begin{array}{c}\text { listin } \\
\mathrm{g}\end{array}$ & $\begin{array}{c}\text { cashs } \\
\text { ub }\end{array}$ & $\begin{array}{l}\mathrm{t} \\
\mathrm{m}\end{array}$ \\
\hline cash & 1 & & & & & & & & & & & & & & \\
\hline custo & 0.05 & 1 & & & & & & & & & & & & & \\
\hline mer & $4^{* * *}$ & & & & & & & & & & & & & & \\
\hline suppl & 0.00 & 0.276 & 1 & & & & & & & & & & & & \\
\hline $\mathrm{y}$ & $1^{*}$ & $* * *$ & & & & & & & & & & & & & \\
\hline \multirow[t]{2}{*}{ ic } & 0.08 & -0.10 & -0.10 & 1 & & & & & & & & & & & \\
\hline & $4^{* * *}$ & $3^{* * *}$ & $6^{* * *}$ & & & & & & & & & & & & \\
\hline contr & 0.06 & 0.054 & 0.08 & -0.03 & 1 & & & & & & & & & & \\
\hline ol & $2^{* * * *}$ & $* * *$ & $2^{* * * *}$ & $8^{* * *}$ & & & & & & & & & & & \\
\hline \multirow[t]{2}{*}{ aud } & -0.02 & -0.01 & -0.07 & 0.02 & 0.05 & 1 & & & & & & & & & \\
\hline & $7^{* *}$ & $0^{* *}$ & $7^{* * *}$ & $5^{* *}$ & $4^{* * *}$ & & & & & & & & & & \\
\hline \multirow[t]{2}{*}{ size } & -0.13 & -0.21 & -0.21 & 0.28 & -0.27 & 0.04 & 1 & & & & & & & & \\
\hline & $4^{* * *}$ & $0^{* * *}$ & $9^{* * *}$ & $8^{* * *}$ & $9^{* * *}$ & $6^{* * *}$ & & & & & & & & & \\
\hline \multirow[t]{2}{*}{ lev } & -0.27 & -0.10 & -0.08 & -0.06 & -0.28 & -0.05 & 0.43 & 1 & & & & & & & \\
\hline & $3^{* * *}$ & $4^{* * *}$ & $4^{* * *}$ & $5^{* * *}$ & $5^{* * *}$ & $5^{* *}$ & $4^{* * * *}$ & & & & & & & & \\
\hline \multirow[t]{2}{*}{ beta } & -0.07 & 0.031 & -0.00 & 0.00 & -0.04 & -0.02 & -0.00 & $0.05^{*}$ & 1 & & & & & & \\
\hline & $1^{* * * *}$ & $* *$ & $1^{* *}$ & $5^{* * *}$ & $1^{* * *}$ & $1^{*}$ & $4^{*}$ & ** & & & & & & & \\
\hline \multirow[t]{2}{*}{$\mathrm{cf}$} & 0.15 & -0.06 & -0.04 & 0.19 & 0.00 & 0.02 & 0.05 & -0.15 & -0.09 & 1 & & & & & \\
\hline & $4^{* * *}$ & $8^{* * *}$ & $1^{* * *}$ & $5^{* * *}$ & $9^{*}$ & $1^{*}$ & $1^{* * *}$ & $3^{* * *}$ & $* * *$ & & & & & & \\
\hline tobin & 0.22 & 0.147 & 0.10 & -0.00 & 0.16 & 0.01 & -0.42 & -0.43 & -0.21 & 0.15 & 1 & & & & \\
\hline $\mathrm{q}$ & $5^{* * *}$ & $* * *$ & $3^{* * *}$ & 2 & $6^{* * *}$ & $4^{*}$ & $8^{* * *}$ & $7^{* * * *}$ & $* * *$ & $7^{* * *}$ & & & & & \\
\hline dumd & 0.111 & -0.09 & -0.10 & 0.31 & -0.01 & 0.00 & 0.17 & -0.09 & 0.03 & 0.14 & -0.04 & 1 & & & \\
\hline ivi & ${ }^{* * *}$ & $3^{* * *}$ & $6^{* * *}$ & $2^{* * *}$ & $3^{* * *}$ & $7^{*}$ & $0^{* * *}$ & $7^{* * *}$ & $7^{* * *}$ & $7^{* * *}$ & $3^{* * *}$ & & & & \\
\hline listin & -0.10 & -0.04 & -0.04 & -0.06 & -0.43 & -0.03 & 0.28 & 0.35 & -0.07 & 0.00 & -0.11 & -0.11 & 1 & & \\
\hline g & $6^{* * *}$ & $7^{* * *}$ & $6^{* * * *}$ & $6^{* * *}$ & $9^{* * * *}$ & $8^{* * * *}$ & $7^{* * *}$ & $7^{* * *}$ & $8^{* * *}$ & $2^{* * * *}$ & $8^{* * *}$ & $8^{* * * *+}$ & & & \\
\hline
\end{tabular}




\begin{tabular}{llllllllllllllllll}
\hline cashs & 0.04 & 0.098 & 0.02 & 0.07 & 0.22 & 0.07 & -0.26 & -0.26 & -0.01 & -0.07 & 0.26 & 0.04 & -0.27 & 1 & \\
ub & $6^{* * * *}$ & $* * *$ & $4^{*}$ & $7^{* * *}$ & $3^{* * *}$ & $2^{* * *}$ & $2^{* * *}$ & $6^{* * *}$ & $4^{* * *}$ & $0^{* * *}$ & $7^{* * *}$ & $8^{* * * *}$ & $5^{* * *}$ & \\
tmde & 0.17 & 0.058 & 0.04 & -0.01 & 0.12 & -0.03 & -0.30 & -0.18 & -0.07 & 0.04 & 0.17 & 0.00 & -0.13 & -0.00 & 1 \\
bt & $9^{* * * *}$ & & $1^{* * * *}$ & $4^{* * *}$ & $7^{* * *}$ & $3^{* * *}$ & $3^{* * *}$ & $8^{* * *}$ & $0^{* * *}$ & $9^{* * *}$ & $8^{* * *}$ & $5^{* * *}$ & $1^{* * *}$ & $2^{* * *}$ \\
\hline
\end{tabular}

Note: ***, **, * represent significance levels of $1 \%, 5 \%, 10 \%$ respectively.

\subsection{Regression Results and Analysis}

\subsubsection{The Influence of Suppliers/Clients on Cash Holding Level}

Table 4 listed the regression results of suppliers/clients and cash holding level. (1) In regression 1 , the supplier has significantly negative effect on cash of significant level of $10 \%$ and the parameter is estimated to be -0.1 , which means other equal, for every unit the supply increases, the cash reduces by an average of 0.1 units, the value of $\mathrm{F}$ is 62.72 and has good explanatory capacity, and the adjusted goodness of fit is $13.37 \%$, assuming H1 (b) stands. (2) In regression 2, customer has significantly positive effect on cash of significant level of $1 \%$, and the parameter is estimated to be 0.159 , which means other equal, for every unit the customer increases, the cash increases by an average of 0.159 units, the value of $\mathrm{F}$ is 82.69 and has good explanatory capacity, and the adjusted goodness of fit is $14.27 \%$, assuming H1(a) stands.

According to market category of supplier relationship trading and customer relationship trading of receivables turnover and accounts payable turnover, this paper respectively studied the influence of supplier relationship trading and customer relationship trading on cash holding level in buyer's market and seller's market. Regression 3-6 is the regression results that differentiate supplier relationship trading and customer relationship trading and cash holding level of supplier/customer in the buyer's and seller's markets respectively. First, Regressions 3 and 4 have shown that when customer trading happens in the buyer's market, the coefficient of customer is 0.214 and has a significance level of $1 \%$, the value of $\mathrm{F}$ is 98.80 , and the adjusted goodness of fit is $20.09 \%$, meaning that the influence of customer concentration to cash holding is significantly positive; however, in the seller's market, the regression results are insignificant. It is assumed that when customer relationship trading is in the buyer's market, the corporation is in a passive position as a result of seeking for higher and more stable access for sales, and the high concentration of customers will make corporations hold more cash so as to prevent the risk of relationship trading. Second, Regressions 5 and 6 have shown that when supplier relationship trading is in buyer's market, the coefficient of supply is -0.391 and is significant at the significance level of $1 \%$, the value of $\mathrm{F}$ is 29.90 and the adjusted goodness of fit is $25.05 \%$, meaning that the influence of supplier concentration to cash holding is significantly negative; however, in the seller's market, the regression result is insignificant. Therefore, it is assumed that when supplier relationship trading is in buyer's market, a corporation has strong market position as well as negotiation ability and therefore there is no need for excessive cash to maintain relationship trading; instead, the cash can be used for investment and other aspects. 
Table 4 Regression Results of Supplier/Customer Relationship Trading and Cash Holding Level

\begin{tabular}{|c|c|c|c|c|c|c|}
\hline VARIABLES & Regression 1 & Regression 2 & $\begin{array}{c}\text { Regression 3: } \\
\text { Buyer }\end{array}$ & $\begin{array}{c}\text { Regression 4: } \\
\text { Seller }\end{array}$ & $\begin{array}{c}\text { Regression 5: } \\
\text { Buyer }\end{array}$ & $\begin{array}{c}\text { Regression 6: } \\
\text { Seller }\end{array}$ \\
\hline ic & $\begin{array}{l}0.0379^{* * *} \\
(0.0121)\end{array}$ & $\begin{array}{l}0.0412^{* * *} \\
(0.0113)\end{array}$ & $\begin{array}{l}0.0256^{*} \\
(0.0131)\end{array}$ & $\begin{array}{l}0.0834^{* * *} \\
(0.0231)\end{array}$ & $\begin{array}{l}0.0832^{* * *} \\
(0.0238)\end{array}$ & $\begin{array}{l}0.0236^{*} \\
(0.0141)\end{array}$ \\
\hline customer & & $\begin{array}{l}0.159^{* * * *} \\
(0.0534)\end{array}$ & $\begin{array}{l}0.214^{* * * *} \\
(0.0574)\end{array}$ & $\begin{array}{l}-0.0936 \\
(0.147)\end{array}$ & & \\
\hline supply & $\begin{array}{l}-0.100^{* * *} \\
(0.0582)\end{array}$ & & & & $\begin{array}{l}-0.391^{* * *} \\
(0.119)\end{array}$ & $\begin{array}{c}0.0176 \\
(0.0679)\end{array}$ \\
\hline control & $\begin{array}{l}-0.0536^{* *} \\
(0.0248)\end{array}$ & $\begin{array}{l}-0.0337 \\
(0.0225)\end{array}$ & $\begin{array}{l}-0.0519^{* *} \\
(0.0247)\end{array}$ & $\begin{array}{l}0.00656 \\
(0.0534)\end{array}$ & $\begin{array}{l}-0.0741 \\
(0.0562)\end{array}$ & $\begin{array}{l}-0.0594^{* *} \\
(0.0276)\end{array}$ \\
\hline aud & $\begin{array}{l}-0.0610^{* * *} \\
(0.0219)\end{array}$ & $\begin{array}{l}-0.0569^{* * *} \\
(0.0201)\end{array}$ & $\begin{array}{l}-0.0568^{* *} \\
(0.0221)\end{array}$ & $\begin{array}{l}-0.0672 \\
(0.0484)\end{array}$ & $\begin{array}{l}-0.0771 \\
(0.0508)\end{array}$ & $\begin{array}{l}-0.0609^{* *} \\
(0.0243)\end{array}$ \\
\hline size & $\begin{array}{l}0.00538 \\
(0.0128)\end{array}$ & $\begin{array}{l}0.00628 \\
(0.0118)\end{array}$ & $\begin{array}{l}0.0232^{*} \\
(0.0139)\end{array}$ & $\begin{array}{l}-0.0219 \\
(0.0248)\end{array}$ & $\begin{array}{l}-0.0316 \\
(0.0266)\end{array}$ & $\begin{array}{l}0.0279^{*} \\
(0.0153)\end{array}$ \\
\hline lev & $\begin{array}{l}-1.231^{* * *} \\
(0.0883)\end{array}$ & $\begin{array}{l}-1.394^{* * *} \\
(0.0800)\end{array}$ & $\begin{array}{l}-1.457^{* * *} \\
(0.0876)\end{array}$ & $\begin{array}{l}-1.128^{* * *} \\
(0.202)\end{array}$ & $\begin{array}{l}-0.934^{* * *} \\
(0.213)\end{array}$ & $\begin{array}{l}-1.316^{* * *} \\
(0.0977)\end{array}$ \\
\hline beta & $\begin{array}{l}-0.0801 \\
(0.0491)\end{array}$ & $\begin{array}{l}-0.102^{* *} \\
(0.0452)\end{array}$ & $\begin{array}{l}-0.152^{* * *} \\
(0.0509)\end{array}$ & $\begin{array}{c}0.114 \\
(0.0988)\end{array}$ & $\begin{array}{l}0.0785 \\
(0.103) \\
\end{array}$ & $\begin{array}{l}-0.111^{* * *} \\
(0.0559)\end{array}$ \\
\hline cf & $\begin{array}{l}0.721^{* * *} \\
(0.169)\end{array}$ & $\begin{array}{l}0.618^{* * *} \\
(0.153)\end{array}$ & $\begin{array}{l}0.500^{* * *} \\
(0.174)\end{array}$ & $\begin{array}{l}0.846^{* * *} \\
(0.327)\end{array}$ & $\begin{array}{l}0.930^{* * *} \\
(0.347)\end{array}$ & $\begin{array}{l}0.634^{* * *} \\
(0.195)\end{array}$ \\
\hline tobinq & $\begin{array}{l}0.0765^{* * *} \\
(0.0083)\end{array}$ & $\begin{array}{l}0.0592^{* * *} \\
(0.0076)\end{array}$ & $\begin{array}{l}0.0485^{* * *} \\
(0.0082)\end{array}$ & $\begin{array}{l}0.127^{* * *} \\
(0.0209)\end{array}$ & $\begin{array}{l}0.136^{* * * *} \\
(0.0219)\end{array}$ & $\begin{array}{l}0.0665^{* * *} \\
(0.0088)\end{array}$ \\
\hline dumdivi & $\begin{array}{l}0.104^{* * *} \\
(0.0231)\end{array}$ & $\begin{array}{l}0.120^{* * *} \\
(0.0213) \\
\end{array}$ & $\begin{array}{l}0.143^{* * *} \\
(0.0233) \\
\end{array}$ & $\begin{array}{c}0.000665 \\
(0.0509) \\
\end{array}$ & $\begin{array}{r}-0.0554 \\
(0.0534) \\
\end{array}$ & $\begin{array}{l}0.138^{* * *} \\
(0.0255)\end{array}$ \\
\hline listing & $\begin{array}{l}-0.00179 \\
(0.0023)\end{array}$ & $\begin{array}{l}-0.0035^{*} \\
(0.0021)\end{array}$ & $\begin{array}{l}-0.0061^{* * *} \\
(0.0023)\end{array}$ & $\begin{array}{c}0.0055 \\
(0.0049)\end{array}$ & $\begin{array}{c}0.0063 \\
(0.0051)\end{array}$ & $\begin{array}{l}-0.0041 \\
(0.0025)\end{array}$ \\
\hline cashsub & $\begin{array}{l}-0.769^{* * *} \\
(0.0797)\end{array}$ & $\begin{array}{l}-0.895^{* * *} \\
(0.0731)\end{array}$ & $\begin{array}{l}-0.947^{* * *} \\
(0.0826)\end{array}$ & $\begin{array}{l}-0.782^{* * *} \\
(0.178)\end{array}$ & $\begin{array}{l}-0.603^{* * *} \\
(0.184)\end{array}$ & $\begin{array}{l}-0.858^{* * *} \\
(0.0916)\end{array}$ \\
\hline tmdebt & $\begin{array}{l}0.457^{* * *} \\
(0.0747)\end{array}$ & $\begin{array}{l}0.518^{* * *} \\
(0.0688)\end{array}$ & $\begin{array}{l}0.434^{* * *} \\
(0.0768)\end{array}$ & $\begin{array}{l}0.775^{* * *} \\
(0.156)\end{array}$ & $\begin{array}{l}0.802^{* * *} \\
(0.164)\end{array}$ & $\begin{array}{l}0.351^{* * *} \\
(0.0839)\end{array}$ \\
\hline capexp & $\begin{array}{l}-0.367^{* * *} \\
(0.0231)\end{array}$ & $\begin{array}{l}-0.197^{* * *} \\
(0.0047)\end{array}$ & $\begin{array}{l}-0.328^{* * *} \\
(0.0264)\end{array}$ & $\begin{array}{l}-0.217^{* * *} \\
(0.0459)\end{array}$ & $\begin{array}{l}-0.186^{* * *} \\
(0.0474)\end{array}$ & $\begin{array}{l}-0.322^{* * *} \\
(0.0282)\end{array}$ \\
\hline Constant & $\begin{array}{l}0.917^{* * *} \\
(0.3130)\end{array}$ & $\begin{array}{l}0.913^{* * *} \\
(0.2860)\end{array}$ & $\begin{array}{l}0.329^{* * *} \\
(0.0667)\end{array}$ & $\begin{array}{c}0.287^{* *} \\
(0.1250)\end{array}$ & $\begin{array}{l}0.354^{* * *} \\
(0.1310)\end{array}$ & $\begin{array}{l}0.309^{* * *} \\
(0.0717)\end{array}$ \\
\hline Industry/Year & Control & Control & Control & Control & Control & Control \\
\hline F Value & 62.72 & 82.69 & 98.80 & 34.34 & 29.90 & 77.34 \\
\hline $\mathrm{Pr}>\mathrm{F}$ & $<0.0001$ & $<0.0001$ & $<0.0001$ & $<0.0001$ & $<0.0001$ & $<0.0001$ \\
\hline Observations & 5,199 & 6,379 & 5,057 & 1,322 & 1,123 & 4,076 \\
\hline R-squared & 0.1359 & 0.1445 & 0.2029 & 0.2542 & 0.2592 & 0.1983 \\
\hline Adj R-squared & 0.1337 & 0.1427 & 0.2009 & 0.2468 & 0.2505 & 0.1958 \\
\hline
\end{tabular}

Note: All values of $\mathrm{P}$ in brackets have been adjusted by $\mathrm{ARCH}$, and ***, **, * represent significance levels of $1 \%, 5 \%, 10 \%$ respectively. 


\subsubsection{The Modification Effect of Internal Control to the Influence of Relationship Trading on Cash Holding Level}

In order to inspect the modification effects of the influence of internal control to relationship trading on cash holding, corporate cash holding level for regression has been divided according to the professional median. When the cash holding level is higher than the median, it is assumed that cash holding level is high; and when cash holding level is lower than the median, it is assumed that cash holding level is low. Given the above grouping, the results are shown in Table 5. (1) When cash holding level is low, a great number of relationship trading will reduce corporate cash holding level, and if the cash holding level is low, it will do no good to the corporation. Internal control, however, can adjust this kind of harmful decrease in cash holding. From Group 1, it can be seen that when cash holding level is low, the effect of ic supply on cash is negative on the significance level of 5\%, namely, with the increase in the quality of internal control, the reduction of cash holding level induced by supplier relationship trading will be mitigated, which is very significant when cash holding level is low. (2) When the cash holding level is high, high cost of customer relationship trading will lead to the increase of cash holding level, and if corporate cash holding level is too high, internal control will adjust this kind of higher-than-average cash holding. From Group 2, it can be noticed that when cash holding level is high, the effect of ic customer on cash is negative on the significance level of 5\%, namely, with the increase in the quality of internal control, the influence of customer relationship trading to cash holding will be reduced, which is significant when the cash holding level is high. Hypothesis 2 is therefore verified.

Table 5 Regression Results of the Regulating Effect of Internal Control to the Influence of Relationship Trading on Cash Holding Level

\begin{tabular}{|c|c|c|c|c|}
\hline \multirow[b]{2}{*}{ VARIABLES } & \multicolumn{2}{|c|}{ Group1: Low Cash Holding Level } & \multicolumn{2}{|c|}{ Group2: High Cash Holding Level } \\
\hline & cash & cash & cash & cash \\
\hline ic & $\begin{array}{l}0.0285^{* * *} \\
(0.0074)\end{array}$ & $\begin{array}{l}0.0154^{* * *} \\
(0.0058)\end{array}$ & $\begin{array}{c}0.0115 \\
(0.0351)\end{array}$ & $\begin{array}{l}-0.0100 \\
(0.0300)\end{array}$ \\
\hline supply & $\begin{array}{l}-0.0505^{* * *} \\
(0.0194)\end{array}$ & & $\begin{array}{l}-0.3420^{* * * *} \\
(0.0934)\end{array}$ & \\
\hline customer & & $\begin{array}{l}0.0426^{* *} \\
(0.0089)\end{array}$ & & $\begin{array}{l}0.2180^{* * *} \\
(0.0071)\end{array}$ \\
\hline ic_supply & $\begin{array}{l}-0.0358^{* *} \\
(0.0072)\end{array}$ & & $\begin{array}{r}-0.0503 \\
(0.0877) \\
\end{array}$ & \\
\hline ic_customer & & $\begin{array}{c}0.0012 \\
(0.0168)\end{array}$ & & $\begin{array}{l}-0.0320^{* *} \\
(0.0805)\end{array}$ \\
\hline Control Variables & control & control & control & control \\
\hline Constant & $\begin{array}{l}0.3640^{* * *} \\
(0.1060)\end{array}$ & $\begin{array}{l}0.3960^{* * *} \\
(0.0955)\end{array}$ & $\begin{array}{l}0.9640^{* *} \\
(0.4900)\end{array}$ & $\begin{array}{l}0.8990^{* *} \\
(0.4430)\end{array}$ \\
\hline Observations & 2,716 & 3,190 & 2,483 & 3,189 \\
\hline R-squared & 0.0971 & 0.0973 & 0.1222 & 0.1254 \\
\hline
\end{tabular}

Note: All values of $\mathrm{P}$ in brackets have been adjusted by $\mathrm{ARCH}$, and $* * *,{ }^{* *},{ }^{*}$ represent significance levels of $1 \%, 5 \%, 10 \%$ respectively. Due to the limited article length, control variables in the table will not be listed one by one, and sources are ready for search. 


\subsection{Robustness Test}

In order to maintain the robustness of the regression results, tests have been conducted: first, explained variables are defined as cash holding level=cash and cash equivalents/total capital, and the new regression results keeps the same. Second, growth for the main business income is adopted to replace Tobin Q to measure corporate growth opportunities. Growth= (the current main business income-main business income of the previous period)/main business income of the previous period. The regression results are basically unchanged.

\section{Conclusions and Limitations}

Adopting the manufacture industry of listing companies in 2009-2015, the research has theoretically analyzed and empirically verified the influence of relationship trading to cash holding level and further inspected the regulating effect of internal control upon this influence. Research shows; (1) the increase in customer relationship trading leads to the increase of corporate cash holding level; while the increase of supplier relationship trading leads to the decrease of corporate cash holding and it is more significant in the buyer's market. (2) When the cash holding level is high, internal control can reduce the increase in cash holding level induced by large amounts of customer relationship trading; when the cash holding level is low, internal control can mitigate the decrease in cash holding level induced by large amounts of supplier relationship trading so as to keep a reasonable corporate cash holding level and increase the efficiency of cash holding and allocation.

The limitation of the article lies in: (1) the substitution variables of relationship trading are to be further specified. In this article, what is adopted are "the ratio of sales figure of the first 5 customers to the total sales revenue" and "the ratio of purchase price of the first 5 suppliers to the total purchase price" reported by listing companies. So as to the details about the "first 5", there is no release and the heterogeneity of the "first 5" may have different effects. Thus, new set of rules and standards as well as the details about the first 5 suppliers and customers purchase price and ratios of each companies are to be expected and perfected, and they will be emphasized in future research. (2) The internal control level adopted database provided by DIB Risk Management Company which has been widely applied by many scholars at home and abroad, but due to the fact that this index is calculated through significance augmented assignment with many factors, they have certain overlap with other index (variables). However, limited by the level of understanding and the data sources, there are not any available supplementary index that is more scientific and reasonable for now, which is also a common focus for the issue in later research.

\section{Acknowledgements}

This paper has been supported by National Natural Science Foundation of China (Project No. 71272220 and Project No.71572002) and by National Social Science Foundation of China (Project No. 15BYY024).

\section{References}

[1] Jeffrey H. Dyer, Harbir Singh. The relational view: Cooperative strategy and sources of interorganizational competitive advantage [J]. Academy of Management Review, 1998(23): 660-679. 
[2] Jeffrey H. Dyer, Wujin Chu. The role of trustworthiness in reducing transaction costs and improving performance: Empirical evidence from the United States, Japan, and Korea [J]. Organization Science, 2003(14): 13-28.

[3] Xiang Kong. Why are social network transactions important? Evidence based on the concentration of key suppliers and customers in China [J]. China Journal of Accounting Research, 2011(4): 121-133.

[4] Kai Wai Hui, Sandy Klasa, P. Eric Yeung. Corporate suppliers and customers and accounting conservatism [J]. Journal of Accounting and Economics, 2012(53): 115-135.

[5] Sanford J. Grossman, Oliver D. Hart. The costs and benefits of ownership: A theory of vertical and lateral integration [J]. Journal of Political Economy, 1986, 94(4): 691-719.

[6] Simon Johnson, Daniel Kaufmann, John McMillan, Christopher Woodruff. Why do firms hide? Bribes and unofficial activity after communism [J]. Journal of Public Economics, 2000(76): 495-520.

[7] Oliver Williamson. The economic institutions of capitalism [M]. Beijing: Commercial Press, 2002.

[8] Ming Jian, Tak Jun Wong. Propping through related party transactions [J]. American Economics Review, 2010(15): 70-105.

[9] Jin Li, Stewart C. Myers. $\mathrm{R}^{2}$ around the world: new theory and new tests [J]. Journal of Financial Economics, 2006, 79(2): 257-292.

[10] Zengquan Li, Qing Ye, Hui He. Corporate relevance, information transparency and share price characteristics [J]. Accounting Research, 2011(1): 44-51.

[11] Yiwei Dou, Ole-Kristian Hope, Wayne B. Thomas. Relationship-specificity, contract enforceability, and income smoothing [J]. The Accounting Review, 2013, 88( 5): 1629-1656.

[12] Guoshun Wang, Yong Zhou, Jie Tang. Trade, governance and economic efficiency [M]. Beijing: China Economic Publishing House, 2005.

[13] Bradford Cornell, Alan C. Shapiro. Corporate stakeholders and corporate finance [J]. Financial Management, 1987, 16(1): 5-14.

[14] Huili Zhang, Youhong Wu. Internal control, cash holdings and economic consequences [J]. Accounting Research, 2014(3): 71-96.

[15] Yanchao Wang, Shunlin Song. Connected transaction, internal control and cash holding [J]. Review of Investment Studies, 2014, 33(6): 55-67.

[16] Yuejun Tang. Supplier, dealer bargaining power and company performance- Empirical evidence from 2005-2007 China manufacturing listed companies [J]. China Industrial Economics, 2009(10): 67-76.

[17] Kai Wai Hui, Sandy Klasa, P. Eric Yeung. Corporate suppliers and customers and accounting conservatism [J]. Journal of Accounting and Economics, 2012(53): 115-135.

[18] Yong Wang, Zhiyuan Liu. Supplier-customer relationship and enterprise cash holding: Empirical evidence from listed companies of China manufacturing industry [J]. Journal of Audit \& Economics, 2016(1): 83-91.

[19] Xiuyun Zhao, Qun Bao. Institutional environment, relational transaction and cash holdings policy [J]. Journal of Audit \& Economics, 2015(3): 21-29.

[20] Jennifer Itzkowitz. Customers and cash: how relationships affect suppliers' cash holdings [J]. Journal of Corporate Finance, 2013(19): 159-180.

[21] Dan Yang, Limei Wan, Beibei Hou. Information transparency of internal control and equity agency cost-Empirical evidence based on A-share mainboard manufacturing listed companies 
[J]. Review of Investment Studies, 2013, 32(3): 98-113.

[22] John Maynard Keynes. The general theory of employment, interest and money [M], London: Harcourt, 1936.

[23] Jarrad Harford, Sattar A. Mansi, William F. Maxwell. Corporate governance and a firm's cash holdings [R], AFA 2006 Boston Meetings Paper, 2006: 1-31.

[24] Xuefeng Chen, Junyi Weng. Cash holding and operating performance of rights issue companies [J]. Policy-Making Reference, 2002, 15(4): 37-41.

[25] Shaofei Wang, Guoliang Zhou, Xiaoyang He, Xuhui Yu. Relationship-specific investment and auditors' behavior [J]. Journal of Finance and Economics, 2010, 36(5): 16-26.

[26] Min Zhang, Lijun Ma, Sheng Zhang. Supplier-customer relationship and auditor selection [J]. Accounting Research, 2012(12): 81-86. 